\title{
Psychometric Analysis of the Ryff's Psychological Well-Being Scales in Students of Four Mexican Universities
}

\author{
Patricia Balcázar Nava1, Oscar Armando Esparza del Villar², Gloria Margarita Gurrola Peña1, \\ National Network of Studies on Violence and Health*
}

${ }^{1}$ Universidad Autónoma del Estado de México, Mexico

${ }^{2}$ Universidad Autónoma de Ciudad Juárez Mexico

Email: pbalcazarnava@hotmail.com

How to cite this paper: Nava, P. B., del Villar, O. A. E., Peña, G. M. G., \& National Network of Studies on Violence and Health (2018). Psychometric Analysis of the Ryff's Psychological Well-Being Scales in Students of Four Mexican Universities. Psychology, 9, 2685-2708.

https://doi.org/10.4236/psych.2018.913154

Received: August 21, 2018

Accepted: December 3, 2018

Published: December 6, 2018

Copyright $(9) 2018$ by authors and Scientific Research Publishing Inc. This work is licensed under the Creative Commons Attribution International License (CC BY 4.0).

http://creativecommons.org/licenses/by/4.0/

\begin{abstract}
The objective of this research was to study the psychometric properties of the Ryffs Psychological Well-Being Scales in the version of 39 items (Díaz et al., 2006) with samples from four Mexican universities. First, an exploratory factorial analysis was performed with 754 university students, testing different models according to the literature; the model with the best fit was the one that grouped the 31 items in three factors: Tendency to self-actualization, interpersonal and intrapersonal relations and Autonomy, with a total internal reliability of $\alpha=.77$. In the second phase, we worked with 753 participants, with whom we performed a confirmatory analysis of which we obtained goodness of fit indices indicating a good model according to the criteria proposed by $\mathrm{Hu}$ and Bentler (1999). The factor loadings of the items were between .35 and .81 , and the internal reliability of the test was $\alpha=.73$. The findings confirm what other authors have concluded in this respect, that the hexa dimensional structure of the original model is not replicated.
\end{abstract}

\footnotetext{
${ }^{*}$ National Network of Studies in Violence and Health, co-author of this article, comprises the following researchers: Cuerpo Académico "Clínica y Familia", Universidad Autónoma del Estado de México (Moysén-Chimal, A., Villaveces-López, M.C., Estrada-Laredo, E. \& Garay-López, J.C.): Cuerpo Académico "Experimental y Clínica de la Salud", Universidad Autónoma de Ciudad Juárez (Carrillo-Saucedo, I.C., Montañez-Alvarado, P. \& Gutiérrez-Vega, M.); Cuerpo Académico "Psicología Clínica de la Salud”, Universidad Autónoma de Ciudad Juárez (González-Valles, M.A., Vidaña-Gaytán, M.E. \& Castro-Valles, A.); Cuerpo Académico "Estudios de Psicología", Universidad Autónoma de Tamaulipas (Orozco-Ramírez, L.A., Ybarra-Sagarduy, J.L., Almanza-Avendaño, A.M. \& Gómez-San Luis, A.H.) \& Cuerpo Académico "Niños, Jóvenes y Cognición Social, Universidad Autónoma de Zacatecas (García-Sánchez, M.D., Lozano-Razo, G. \& Zavala-Rayas, J.). This study was funded by PRODEP, SEP, research project "Indicadores de ajuste psicosocial en jóvenes víctimas de violencia comunitaria".
} 


\section{Keywords}

Psychological Well-Being, Psychometric Properties, Structural Equation Model, University Students

\section{Introduction}

For the Spanish Royal Academy (2014), happiness is defined as a state of gratifying satisfaction of spiritual and physical type or, as the absence of inconveniences. For Marías (1987), from the philosophical point of view, happiness is the ultimate good or objective to which the human being would tend as a rational being, although it is subjective and will depend on what each one understands as "ultimate good"; due to this relativity, the subject has been studied since ancient times, by philosophers like Plato, Aristotle and Epicurus, who dedicated complete works around the term.

The concept of happiness is closely related to concepts such as material and personal resources, pleasure, the notion of success, power, wealth, belongings and well-being; in addition to philosophy, happiness has been studied from sociology and psychology, among other disciplines. In psychology, the term "well-being" as a construct was derived from the concept of happiness, and in many cases, it has been equated with the constructs of quality of life, personal satisfaction or life purpose, depending on the authors that address the issue. Thus, it also depends on the focus from which the concept is studied, its consideration as a transient state or as a distinctive personality trait.

The study of well-being is one of the topics in the emerging positive psychology that has been systematically studied for more than four decades (Ballesteros, Medina, \& Caycedo, 2006; Casas, Rosich, \& Alsinet, 2000; Castro-Solano, 2009; Casullo \& Castro-Solano, 2002; Cornejo \& Lucero, 2005; Costa \& McCrae, 1980; García-Viniegras \& González-Benítez, 2000; Oramas Vieyra, Santana López, \& Vergara Barrenechea, 2006; Ryff, 1989a; Villar, Triadó, Resano, \& Osuna, 2003).

In the approach to this construct, there are two traditions or views from which two constructs derive: subjective well-being and psychological well-being, and that according to the literature review, different authors mention it (Abott et al., 2006; Barrantes-Brais \& Ureña-Bonilla, 2015; Castro-Solano, 2009; Chitgian-Urzúa, Urzúa \& Vera-Villarroel, 2013; Díaz et al., 2006; Domínguez Lara, 2014; Gallardo \& Moyano-Díaz, 2012; García-Alandete, 2013; García-Viniegras, 2005; Medina-Calvillo, Gutiérrez-Hernández, \& Padrós-Blázquez, 2013; Molina Sena \& Meléndez Moral, 2006; Rosa-Rodríguez \& Quiñones Berrios, 2012; Rosa-Rodríguez, Negrón Cartagena, Maldonado Peña, Quiñones Berrios, \& Toledo Osorio, 2015; Valenzuela, 2015; Véliz, 2012; Vera-Villarroel, Urzúa, Silva, Pavez, \& Celis-Atenas, 2013; Vivaldi \& Barra, 2012).

In the case of the first construct, subjective well-being, the hedonic tradition 
refers to the person's appreciation of his life satisfaction, in which there is an affective or emotional component (Véliz, 2012) and focuses on the balance between positive and negative affects (Gallardo \& Moyano-Díaz, 2012). Studies in this tradition are related to life satisfaction, experiences of happiness and subjective well-being, in which authors like Diener, Lucas, Suh, Venhooven, van Dierendonck, Ryff, Keyes, Deci \& Smith are its representatives. Rosa-Rodríguez et al. (2015) indicate that "it refers to the evaluation of the emotional, affective and cognitive aspects, which in turn include positive affect, negative affect and satisfaction" (p. 32). For Chitgian-Urzúa et al. (2013) subjective well-being focuses on the study of happiness, while the eudemonic tradition, resumes the development of the human potential and therefore, psychological well-being, which will be discussed below and is the central construct of this study.

Psychological well-being is the topic of authors such as Deci \& Ryan (2008), Keyes, Shmotkin, \& Ryff (2002), Ryff \& Singer (2008) and Varelius (2003). The characteristic of this movement is that it is located in the process and attainment of those values that favor the growth of the person, make the him feel alive and authentic; in summary, while the hedonic tradition focuses on pleasure, the eudemonic tradition of psychological well-being resumes the development of the human potential, whose predecessors are in the humanist psychology like Maslow, Rogers, Allport \& Erikson. Ryan \& Deci (2000), precursors of this movement on psychological well-being, indicate that this refers to the development of abilities and personal growth, with the observation that the latter is the main indicator of positive functioning. According to Ryan \& Deci (2000), psychological well-being refers to "the development of abilities and personal growth, considering the latter as the main indicators of positive functioning" (p. 32).

Although there has been a discussion about the dimensions that would integrate the model of psychological wellbeing, perhaps the most representative author of his study is Ryff, who in addition to delving into the construct, operationalized it with the Psychological Well-Being Scales (Gallardo \& Moyano-Díaz, 2012) that have been translated, adapted and tested their psychometric properties in different versions with diverse contexts and populations.

The six dimensions that make up the Scales are (Rosa-Rodríguez et al., 2015, Medina-Calvillo et al., 2013, Molina Sena \& Meléndez Moral, 2006, Valenzuela, 2015, Véliz, 2012):

- Self-acceptance: Refers to the positive self-evaluation that the person has including past and present.

- Autonomy: A sense of self-determination and independence of the person.

- Personal Growth: It has to do with the sense of growth and development as a person.

- Purpose in Life: It is related to the belief that for the person, their life experience has a meaning and a purpose.

- Positive Relations with Others: It refers to having or developing quality relationships with others. 
- Environmental Mastery: It refers to the person's ability to manage the environment and to effectively use the opportunities it provides.

Due to its success as one of the representative constructs of positive psychology and its relative novelty to evaluate the construct, Ryff's Psychological Well-Being Scales (PWBS) were disseminated and translated into different languages, adapted to different samples and the psychometric properties were evaluated. However, there is a controversy about the dimensionality of the Ryff's model, since in replications some studies yield similar results, but others not only fail to obtain the hexadimensional model, but have problems with their psychometric characteristics. An example is the findings of Abott et al. (2006) who, after the review, question whether the Ryff's Scale items purely evaluate a construct or capture information from more than one domain; on the other hand, others propose some models with different number of first order factors or models with second order factors.

The Ryff's PWBS have been translated into Spanish and adapted initially by Díaz et al. (2006) in Mexican samples. The scales have undergone a validation process in adolescents from central Mexico (Loera-Malvaez, Balcázar-Nava, Trejo-González, Gurrola-Peña, \& Bonilla-Muñoz, 2008) and in university students from the north of the Mexico (Valenzuela, 2015), as well as in different Hispanic contexts (see Table 1). As a result of this collection of studies, we find somewhat contradictory findings and in some cases similar difficulties as those found by Abott et al. (2006).

The contradictions of the different authors presented, as described in Table 1, lie in the fact that the hexadimensional model proposed by Ryff has not been confirmed in all cases. Subsequent studies have been carried out to test the psychometric properties of the scales, showing findings that in some cases, reproduce a model of six factors, although with low internal consistencies for the subscales or for the total test. In other studies, factor structures with a different number of factors, or with second-order factors, are confirmed. Findings from other confirmatory factor analysis studies, using structural equation modeling, reveal goodness-of-fit indices which are not entirely acceptable.

The Ryff's PWBS has presented a remarkable heterogeneity in its factorial structures, has been used in various samples, has had varying analysis procedures, with different interpretation criteria in different studies. For this reason, when using the Ryff's PWBS as part of the constructs to be evaluated in a research project on violence and its effects on mental health, we decided to test its psychometric properties, submitting it to an exploratory factor analysis in first term, and then, to a confirmatory factor analysis, using a sample of university-level students.

For this purpose, in addition to the use of exploratory and confirmatory factor analyzes, internal reliability indices were obtained by calculating Cronbach's alpha. The confirmatory factorial analysis was carried out with a structural equation model, which according to Ruiz, Pardo, and San Martin (2010) are part of 
Table 1. Summary of studies conducted with Ryff s PWBS in Spanish.

\begin{tabular}{|c|c|c|c|}
\hline Author(s) & Participants & $\begin{array}{c}\text { Version of the } \\
\text { PWBS }\end{array}$ & $\begin{array}{l}\text { Statistical } \\
\text { Analyses }\end{array}$ \\
\hline $\begin{array}{l}\text { Díaz et al. } \\
(2006)\end{array}$ & $\begin{array}{l}467 \text { people with } \\
\text { ages between } 18 \\
\text { and } 72 \text { years, with } \\
\text { diverse } \\
\text { educational level } \\
\text { and varied } \\
\text { sociodemographic } \\
\text { conditions, of } \\
\text { Spain. }\end{array}$ & $\begin{array}{l}\text { Ryff s PWBS } \\
\text { (1989), of the } \\
\text { version } \\
\text { proposed by van } \\
\text { Dierendonck } \\
\text { (2004), that was } \\
\text { translated and } \\
\text { back-translated } \\
\text { to Spanish by } \\
\text { experts, in its } \\
\text { 39-item version. }\end{array}$ & $\begin{array}{l}\text { Internal reliability } \\
\text { (Cronbach's alpha). } \\
\text { Confirmatory factor } \\
\text { analysis with six } \\
\text { different theoretical } \\
\text { models (one-factor, } \\
\text { two-factor, five-factor, } \\
\text { six-factor, five-factor } \\
\text { with second-order } \\
\text { factor and six-factor } \\
\text { with second-order } \\
\text { factor). }\end{array}$ \\
\hline
\end{tabular}

All of the scales, except for personal growth $(\alpha=.68)$, showed good internal consistencies between .71 and .83; The version proposed by van Dierendonck does not meet the model fit criteria. Therefore, a new version was developed from which items were chosen with inter-item correlations of .30 or higher and

with factor loadings in the remaining dimensions with at least .40 of the factor analysis. Ten items were eliminated, leaving 29 items, which presented good model fit indicators in a six-factor model, with a second order, with alpha values between .70 and .84 .

The exploratory factorial analysis revealed a five-dimensional structure, with 43 items, with Cronbach's alpha values for environmental mastery of .87, self-acceptance of .78, positive relations with others of .80 , autonomy of .69 , and personal growth of .61. The correlations between the total score of the scale with the factors were between -.10 and .34 .

Correlations between the total score of the scale and its factors. Correlations between the scales with age, education level and income. Principal components analysis

Ryff's PWBS

422 adults over 65 (1989), with 54 years of age, retired, with items, translated

Triadó et al. (2007) diverse back-translated sociodemographic from the variables, from Spain.
The correlations between scales were between .08 and .55 ; the highest correlations were between personal growth and purpose in life (eudemonic well-being) and between self-acceptance and environmental mastery (hedonic well-being).

Statistically significant correlations were found between purpose in life and age, between personal growth educational level, purpose in life and educational level, personal growth and income, and purpose in life and income. The factorial analysis of the Ryff Scales with Life Satisfaction and the Geriatric Scale are grouped into two factors related to the eudemonic well-being and the hedonic well-being. The factorial analysis forced to 6 factors does not reproduce the original model so we tested five models where the model of 6 factors with a second order factor was the model that had the best fit.

Conclusions

The analyzis carried out on the original version of van Dierendonck have a general good consistency, but the different model fit values of the models were not satisfactory. As the length of the scale increases, the scale has better model fit values. The differences between the good fit in the van Dierendonck version and the poor fit in the Spanish version may be due to the different characteristics of the samples. The new version, which eliminated 10 items and was composed of 29 items, had a good fit in the theoretical model with six factors and a second order factor and represents the theoretical elements of each of the dimensions well.

The five-factor structure seems consistent with the results obtained in other studies, having the items of the purpose in life dimension distributed in the other factors. The internal reliability indices of the scales were adequate. There are significant correlations between the total score of the scale and each of the five factors.

The The internal consistency is relatively low and does not coincide with what was obtained in previous studies, which indicates on the one hand that longer versions reduce their internal consistency. The strong relationships between personal growth and purpose in life, as well as environmental mastery and self-acceptance (greater than .50) assume that the same underlying constructs are being measured, associations that point to a measure of eudemonic and hedonic well-being respectively, two aspects of the construct of well-being. On the other hand, exploratory and confirmatory analyzes do not replicate the original structure, but the best fit is that of 6 factors with two second order factors, although clearly poor and unsatisfactory, similar to findings with younger samples. to the theory. 


\section{Continued}

\begin{tabular}{|c|c|c|c|c|c|}
\hline $\begin{array}{l}\text { Loera-Malv } \\
\text { aez et al. } \\
(2008)\end{array}$ & $\begin{array}{l}208 \text { high-school } \\
\text { students, aged } 14 \\
\text { to } 18 \text { years, from } \\
\text { Mexico. }\end{array}$ & $\begin{array}{l}\text { Ryff's PWBS } \\
\text { (van } \\
\text { Dierendonck } \\
\text { adapted to the } \\
\text { Spanish by Díaz } \\
\text { et al., 2006), } \\
\text { with } 39 \text { items. }\end{array}$ & $\begin{array}{l}\text { Exploratory factor } \\
\text { analysis and internal } \\
\text { reliability (Cronbach's } \\
\text { alpha). }\end{array}$ & $\begin{array}{l}\text { Four factors were obtained that } \\
\text { grouped } 34 \text { items (self-acceptance, } \\
\text { interpersonal relations, autonomy } \\
\text { and satisfaction with life), with factor } \\
\text { loadings between } .72 \text { and } .41 \text {. The } \\
\text { internal reliabilities calculating } \\
\text { Cronbach's alpha values was for } \\
\text { self-acceptance } .91 \text {; for interpersonal } \\
\text { relations } .75 \text {; for autonomy } .73 \text { and } \\
\text { for satisfaction with life } .64 \text {. }\end{array}$ & $\begin{array}{l}\text { This study reproduces four factors } \\
\text { that are similar to some of the } \\
\text { proposals of the original model, } \\
\text { with good qualities of stability and } \\
\text { consistency. }\end{array}$ \\
\hline $\begin{array}{l}\text { Tomás } \\
\text { Miguel, } \\
\text { Meléndez, } \\
\text { \& Navarro } \\
\text { (2008) }\end{array}$ & $\begin{array}{l}169 \text { people } \\
\text { between } 65 \text { and } 94 \\
\text { years old, retired, } \\
\text { non-institutionaliz } \\
\text { ed and without } \\
\text { severe cognitive } \\
\text { impairment, from } \\
\text { Spain. }\end{array}$ & $\begin{array}{l}\text { Ryffs PWBS, } \\
\text { the version of } 54 \\
\text { items used by } \\
\text { Triadó (2003). }\end{array}$ & $\begin{array}{l}\text { Confirmatory factor } \\
\text { analyzes grouping the } \\
54 \text { items into } 18 \\
\text { indicators (three } \\
\text { indicators for each of } \\
\text { the original six } \\
\text { factors). Items were } \\
\text { clustered based on } \\
\text { what each item } \\
\text { measures conceptually } \\
\text { and on the exploratory } \\
\text { factor analysis results. } \\
\text { Descriptive } \\
\text { information was } \\
\text { analyzed and } \\
\text { correlations among the } \\
\text { factors and indicators } \\
\text { were performed. Eight } \\
\text { models were tested for } \\
\text { which model fit indices } \\
\text { were obtained } \\
\text { (onefactor, twofactors, } \\
\text { fivefactors, fivefactors } \\
\text { with a second-order } \\
\text { factor, sixfactors, six } \\
\text { factors with } \\
\text { two-second order } \\
\text { factors, and six factors } \\
\text { with one of } \\
\text { second-order factor) } \\
\text { according to the } \\
\text { revised literature. }\end{array}$ & $\begin{array}{l}\text { Eight models were tests, each with their } \\
\text { goodness of fit indexes (the first model } \\
\text { with one factor; another with two } \\
\text { factors; one model with five factors; a } \\
\text { five-factor model with a second order } \\
\text { factor; a model with six factors; another } \\
\text { six-factor model with a second-order } \\
\text { factor; a six-factor model with two } \\
\text { second-order factors; and a six-factor } \\
\text { model with a second-order model) } \\
\text { according to the revised literature. None } \\
\text { of the models were considered to be } \\
\text { fully adequate, although the six and } \\
\text { five-factor models with no second-order } \\
\text { factors has the most satisfactory model } \\
\text { fit values, making it difficult to choose } \\
\text { between one or the other, although the } \\
\text { AIC and the chi-square ratio allowed to } \\
\text { choose the one with five factors. The } \\
\text { correlations among factors of both } \\
\text { models were high. The omega } \\
\text { S coefficient }(\Omega) \text { was obtained as the best } \\
\text { alternative to the alpha coefficient, for } \\
\text { both models. In the case of the six-factor } \\
\text { model, the omega values were between } \\
\Omega=.50 \text { and } \Omega=.66 \text {, were the } \\
\text { environmental mastery had the lowest } \\
\text { omega value and for the remaining four } \\
\text { factors the omega values were higher } \\
\text { than } .60 \text {; the five-factor model showed a } \\
\text { reliability of } \Omega=.48 \text { for autonomy, } \\
\text { personal growth, positive relations and } \\
\text { purpose in life, and the highest with } \Omega \\
=.77 \text { for the factors of environmental } \\
\text { mastery and self-acceptance. }\end{array}$ & $\begin{array}{l}\text { The results of the factor analyzes do } \\
\text { not have fully satisfactory model fit } \\
\text { indices in any of the models; } \\
\text { however, the five- and six-factor } \\
\text { models are similar to the results of } \\
\text { other studies. The problem of not } \\
\text { having a six-factor model can be } \\
\text { explained by the overlap between } \\
\text { factors, given the high correlations } \\
\text { among these factors. Choosing } \\
\text { between the five and six-factor } \\
\text { models was difficult since the model } \\
\text { fit indices were similar, although in } \\
\text { the case of the five-factor model, the } \\
\text { internal reliability increases by } \\
\text { joining two factors and doubling the } \\
\text { number of indicators }\end{array}$ \\
\hline $\begin{array}{l}\text { Van } \\
\text { Dierendonc } \\
\text { k, Díaz, } \\
\text { Rodríguez- } \\
\text { Carbajal, } \\
\text { Blanco, \& } \\
\text { Moreno- } \\
\text { Jiménez } \\
\text { (2008) }\end{array}$ & $\begin{array}{l}919 \text { people (592 of } \\
\text { Spain and } 327 \text { of } \\
\text { Colombia), } \\
\text { between } 16 \text { and } 74 \\
\text { years. }\end{array}$ & $\begin{array}{l}\text { Ryff's PWBS, } \\
\text { reduced version } \\
\text { (van } \\
\text { Dierendonck } \\
\text { adapted to } \\
\text { Spanish by Díaz } \\
\text { et al., 2006) with } \\
39 \text { items. }\end{array}$ & $\begin{array}{l}\text { Confirmatory factorial } \\
\text { analyses: one factor } \\
\text { model; two factor model } \\
\text { with positive and } \\
\text { negative items; three } \\
\text { factors; three factors } \\
\text { with a second order } \\
\text { factor; six factors; six } \\
\text { factors with a factor of } \\
\text { Second order with four } \\
\text { indicators; six factors } \\
\text { with a second order } \\
\text { factor. Goodness of fit } \\
\text { index and internal } \\
\text { reliability (Cronbach's } \\
\text { alpha). }\end{array}$ & $\begin{array}{l}\text { The results indicate that the model } \\
\text { with the best fit is the } \\
\text { six-dimensional model and its } \\
\text { Cronbach alpha internal reliability } \\
\text { indices were between } .68 \text { and } .82 \text {. }\end{array}$ & $\begin{array}{l}\text { The Spanish version confirms van } \\
\text { Dierendonck's findings of the } \\
\text { six-factor model, with adequate } \\
\text { factor validity and reliability. An } \\
\text { item was removed from the } \\
\text { personal growth dimension because } \\
\text { it did not have an adequate factor } \\
\text { loading. Thus, the hexadimensional } \\
\text { structure is confirmed against the } \\
\text { three-dimensional structure } \\
\text { proposed by Springer and Hauser in } \\
2006 \text {. }\end{array}$ \\
\hline
\end{tabular}


Gallardo \& $\begin{aligned} & 335 \text { adolescents (van } \\ & \text { between } 14 \text { and } 19 \text { Dierendonck }\end{aligned}$ MoyanoDíaz (2012) $\begin{aligned} & \text { years } \\ & \text { Chile }\end{aligned}$

691 university

Véliz students between 17 and 30 years, from Chile.
Vivaldi \& Barra

(2012)
Ryff s PWBS, reduced version

Internal consistency (Cronbach's alpha).

Construct validity using structural equation models. adapted to Spanish by Díaz et al., 2006) with 39 items. theoretical model with two proposed alternatives.
Ryff's PWBS, reduced version (van Dierendonck adapted to Spanish by Díaz et al., 2006) with 39 items.
Ryff's PWBS, reduced version (van Dierendonck 250 people
between 60 and 87 years, from Chile adapted to Spanish by Díaz et al., 2006) with 39 items. Comparison of the
Exploratory and confirmatory factor analyses. Descriptive analyses for each item. Internal reliability (Cronbach's alpha). Correlations among the scales. Structural equation modeling.
Three scales have a good internal reliability (positive relationships with others .75; purpose in life .78, and self-acceptance .78). The remaining three scales have from acceptable to bad values (autonomy .67; personal growth .63, and environmental mastery .59). The tested models were: The six-dimensional model had the Five factors where self-acceptance and environmental mastery are in one factor, six factors, five factors with self-acceptance and environmental mastery in a factor with a second order factor, six factors with a second order factor, six factors with a second order factor which includes self-acceptance, environmental mastery, personal growth and purpose in life. The model with the best fits is the six-dimensional model with a second-order factor, called personal well-being. Cronbach's alpha reliabilities was between .57 and .78 .

The internal consistency of the six-dimensional model is similar to the original, with the following values in the scales: self-acceptance .79; positive relations with others .75; autonomy .67; environmental mastery .62; purpose in life .54, and personal growth .78 . To verify the dimensionality, two successive analyzes were performed, one of exploratory type that yielded six best fit, although the reliabilities were not quite good. The five-dimensional model had a good fit, similar to the six-dimensional model, but with better reliabilities. It is evident that the high correlation among the scales may be part of the problem.

The hexadimensional model has a reasonable model fit to be used in this sample. High correlations dimensions and another model of six among some dimensions indicate factors was generated, keeping only that they might be redundant and the items with factor loadings equal collinear or greater than .30. The factors were reconfigured, although several items were explained by the same factor. The hexadimensional model had a reasonable model fit with factor loadings between .26 and .72 . The correlations among the factors were in the range between .97 and .55 .

Problems with the internal reliability were detected on two scales, which led to the elimination of three of the seven items from the personal growth scale and to completely eliminate the Internal Consistency (Cronbach's alpha). environmental mastery scale. The final scale was composed of the scales of self-acceptance, positive relations with others, autonomy, personal growth, and purpose in life, with a total of 30 items.
There is no conclusion regarding the scale since the study had a different objective that was not specific to the PWBS. 


\section{Continued}

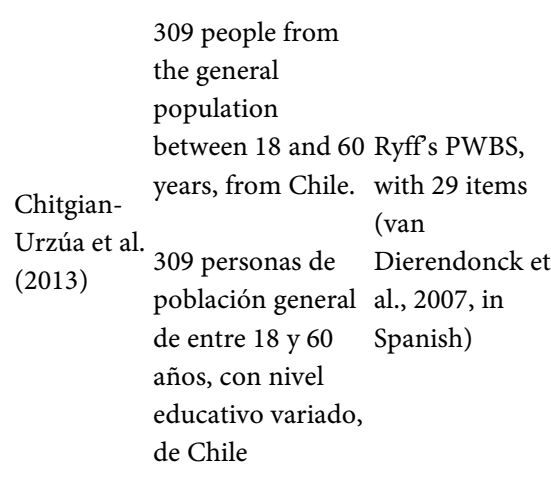

Alandete

(2013)
Ryff's PWBS, 180 undergraduate with 29 items students, aged (van between 18 and 55 , from Spain Dierendonck et al., 2007, in Spanish)
Descriptive analyses. Correlation among items with the total scale score and the different factors. Internal reliability (Cronbach's alpha). Temporal stability assessment (3 weeks interval).

Confirmatory factor analyses with six first order factors, and a second order analysis with one second order factor. Goodness of fit indices were evaluated.

The correlation between the items and the total score of the scale showed values between .29 and .66 . The correlation between the items and their respective dimension, were between .43 and .80 . The internal reliability, using Cronbach's alpha, was .89, and the test-retest reliability had a correlation of .80 . The correlations between the dimensions and the total score of the scale had values between .61 and .82 . There were high correlations between dimensions (self-acceptance and purpose inlife, for example, with value of .77). The data indicated that the first order model of six factors with a second order factor did not fit the proposed model.
The internal consistency was good, although the dimensions had lower values that differed from those of the Spanish version. The test-retest reliability showed an adequate correlation between the applications. There was no good model fit of the data to the six-factor structure, which suggests that it should be further studied, since it does not fit Ryff s original theoretical model. It seems that the environmental mastery and self-acceptance scales, as well as the purpose in life and self-acceptance scales, are highly correlated and might be even measuring the same construct. The model may present adjustment difficulties, given the high correlations between the factors, so it is suggested to re-evaluate the model and to redefine the dimensions and include other concepts related to well-being.

Cronbach's alpha reliabilities for each factor were: self-acceptance 80 , positive relationships with others .76, Descriptive analyses and internal reliability autonomy .74, environmental mastery .64, personal growth .69 ,

samples from Mexico. First sample, 477 university students. Second

Medina- sample, 256

Calvillo et participants from

al. (2013) the general population with different sociodemographic

Ryff's PWBS, reduced version (van Dierendonck adapted to Spanish by Díaz et al., 2006) with levels. No age information provided. and purpose in life .78 . The confirmatory factor analysis of the six-dimensional scale had an adequate model fit.

The study was performed in two stages, a confirmatory factor

(Cronbach's alpha).

Confirmatory factorial analysis was done for each sample
analysis with the first and the goodness of fit was

Cronbach's alpha values of the internal consistencies were acceptable for the total scale, however, those of the subscales were lower than the original ones and those of the study by Díaz et al. sample. Internal acceptable for a six factor model; reliability (Cronbach's Cronbach's alpha was .92 for

alpha), for both Sample A and .90 for Sample B; the Dierendonck's multifactorial samples. Test-retest reliability after a Cronbach's alpha values for the subscales were higher in sample A in the first sample. Test-retest reliability over a theoretical model, nor Ryff s, in contrast to what has been found in countries such as Spain, Turkey, United Kingdom, Iran and Sweden. Descriptive analyses two-month period was $\mathrm{r}=.80$ for the total sum of the scale, while for the subscales the correlations were between .58 and .73 . proposals were suggested, even with different numbers of items. Finally, test-restest reliability suggests that (2006). It seems that the Mexican model does not fit van period of two months and in sample B were much lower.
The internal consistencies reached values between acceptable and high, imilar to those obtained by Díaz et al. (2006). full scale and subscales have temporal stability. 


\begin{tabular}{|c|c|c|c|c|c|}
\hline $\begin{array}{l}\text { Vera- } \\
\text { Villarroel } \\
\text { et al. (2013) }\end{array}$ & $\begin{array}{l}1646 \text { participants } \\
\text { between } 18 \text { and } 90 \\
\text { years, with } \\
\text { different } \\
\text { educational levels } \\
\text { and } \\
\text { sociodemographic } \\
\text { conditions, from } \\
\text { Chile. }\end{array}$ & $\begin{array}{l}\text { Ryff s PWBS, } \\
\text { reduced version, } \\
\text { with } 29 \text { items, } \\
\text { from the version } \\
\text { of Diaz et al. } \\
\text { (2006) and } \\
\text { adapted by } \\
\text { Tomas et al. } \\
(2010) \text {. }\end{array}$ & $\begin{array}{l}\text { Internal reliability } \\
\text { (Cronbach's alpha). } \\
\text { Confirmatory factor } \\
\text { analyzes to evaluate } \\
\text { models of five and six } \\
\text { first order factors, and } \\
\text { six first order factors } \\
\text { with a second order } \\
\text { factor. Test-retest } \\
\text { reliability after three } \\
\text { weeks with a } \\
\text { subsample of } 180 \\
\text { participants. } \\
\text { Correlations between } \\
\text { items of the scales and } \\
\text { their dimensions. }\end{array}$ & $\begin{array}{l}\text { Four of the six dimensions do not } \\
\text { meet the criteria of reliability, having } \\
\text { values below . } 60 \text { in some dimensions } \\
\text { (environmental mastery and personal } \\
\text { growth). The correlations between } \\
\text { each item with the total scale and } \\
\text { with their respective theoretical } \\
\text { dimension were, in most cases, } \\
\text { moderate (between } .50 \text { and } .80 \text { ). } \\
\text { Internal consistencies were } \\
\text { between } .47 \text { and } .82 \text {; the correlations } \\
\text { among factors were between } .47 \\
\text { and } .82 \text {; the construct validity for a } \\
\text { model of five, one of six factors and } \\
\text { one of six with one of the second } \\
\text { order indicated that the best model fit } \\
\text { was for the six-factor model. } \\
\text { Cronbach's alpha values of the } \\
\text { second application were between } .59 \\
\text { and } .82 \text {; the correlations among the } \\
\text { scales were between } .46 \text { and } .79 .\end{array}$ & $\begin{array}{l}\text { The best fit model was that of six } \\
\text { factors without second order } \\
\text { factors, such as the model proposed } \\
\text { by Ryff, a finding that is different } \\
\text { from other studies in which there } \\
\text { was a better fit in the six-factor } \\
\text { model with a second-order model } \\
\text { with detailed analysis done by age } \\
\text { groups. As for the correlation of the } \\
\text { items with their corresponding } \\
\text { theoretical domains, the dimensions } \\
\text { have better correlations in samples } \\
\text { between } 25 \text { and } 65 \text { years. The scale } \\
\text { had a good test-retest reliability. }\end{array}$ \\
\hline $\begin{array}{l}\text { Díaz et al. } \\
\text { (2015) }\end{array}$ & $\begin{array}{l}400 \text { participants } \\
\text { between } 18 \text { and } 64 \\
\text { years of age, from } \\
\text { Colombia and } \\
\text { Spain }\end{array}$ & $\begin{array}{l}\text { Ryff's PWBS, } \\
\text { reduced version } \\
\text { (van } \\
\text { Dierendonck } \\
\text { adapted to } \\
\text { Spanish by Díaz } \\
\text { et al., 2006) with } \\
39 \text { items. }\end{array}$ & $\begin{array}{l}\text { Exploratory factorial } \\
\text { analysis. Descriptive } \\
\text { analyses and analysis } \\
\text { for four models (one } \\
\text { factor, two oblique } \\
\text { factors, two orthogonal } \\
\text { factors, two factors } \\
\text { with a second order } \\
\text { factor called general } \\
\text { well-being). Goodness } \\
\text { of fit indices for the } \\
\text { models. }\end{array}$ & $\begin{array}{l}\text { The analyses indicate that the } \\
\text { model with the best model fit was } \\
\text { that of six factors. A different scale } \\
\text { that measures subjective well-being } \\
\text { was correlated with the PWBS and } \\
\text { the correlation was adequate. The } \\
\text { values of Cronbach's alpha } \\
\text { coefficients of the scales were } \\
\text { between } .68 \text { and } .86 \text {. }\end{array}$ & $\begin{array}{l}\text { The hexadimensional model } \\
\text { proposed by Ryff in different } \\
\text { studies was replicated. }\end{array}$ \\
\hline $\begin{array}{l}\text { Rosa-Rodrí } \\
\text { guez et al. } \\
(2015)\end{array}$ & $\begin{array}{l}768 \text { undergraduate } \\
\text { and graduate } \\
\text { students between } \\
17 \text { and } 74 \text { years, } \\
\text { from Puerto Rico. }\end{array}$ & $\begin{array}{l}\text { Ryff PWBS, } \\
\text { ereduced version } \\
\text { with } 29 \text { items (van } \\
\text { Dierendonck et al., } \\
2007 \text {, in Spanish) } \\
\text { and revised for } \\
\text { linguistic } \\
\text { equivalence. }\end{array}$ & $\begin{array}{l}\text { Descriptive analyses } \\
\text { (Crond internal reliability } \\
\text { (Ch's alpha). }\end{array}$ & $\begin{array}{l}\text { Alpha values were between } .47 \\
\text { and } .80 \text { (environment mastery } \alpha \\
=.47 \text {, personal growth } \alpha=.59 \\
\text { self-acceptance } \alpha=.74 \text {, positive } \\
\text { relations with others } \alpha=.71 \text {, } \\
\text { autonomy } \alpha=.60 \text {, and purpose in } \\
\text { life } \alpha=.80 \text { ). }\end{array}$ & $\begin{array}{l}\text { Findings were similar to other } \\
\text { studies that use the } 29 \text { and } 39 \text { item } \\
\text { scales. The low reliability scores in } \\
\text { the personal growth and } \\
\text { environmental mastery domains } \\
\text { indicate the need to evaluate the } \\
\text { factorial structure of the scales. }\end{array}$ \\
\hline $\begin{array}{l}\text { Valenzuela } \\
(2015)\end{array}$ & $\begin{array}{l}1100 \text { university } \\
\text { students with a } \\
\text { mean age of } 22 \\
\text { years, from } \\
\text { Mexico. }\end{array}$ & $\begin{array}{l}\text { Ryffs PWBS } \\
\text { (Díaz et al., } \\
\text { 2006), in its } 29 \\
\text { items version } \\
\text { from the original } \\
\text { English version, } \\
\text { translated, } \\
\text { back-translated, } \\
\text { and with an } \\
\text { added item to the } \\
\text { personal growth } \\
\text { dimension. The } \\
\text { scale has a total } \\
\text { of } 30 \text { items, five } \\
\text { for each } \\
\text { dimension. }\end{array}$ & $\begin{array}{l}\text { Confirmatory factor } \\
\text { analyses with different } \\
\text { models: one with six } \\
\text { factors, then different } \\
\text { structures. For the six } \\
\text { factors, a confirmatory } \\
\text { e strategy was used and } \\
\text { then exploratory } \\
\text { analyses to test other } \\
\text { models. }\end{array}$ & $\begin{array}{l}\text { The six-factor model has inadequate } \\
\text { fit indices and Cronbach's alpha } \\
\text { values between .41 and .58, far from } \\
\text { the recommended standards. The } \\
\text { structure with the best fit is the } \\
\text { two-factor structure, made up of half } \\
\text { of the items, which presented a low } \\
\text { positive correlation between them } \\
\text { (.10), and with Cronbach's alpha } \\
\text { values for the scales between } .81 \\
\text { and } .86 \text {, which allows us to think } \\
\text { about the interdependence of } \\
\text { dimensions. The two-factor model } \\
\text { consisted of } 15 \text { items, in two } \\
\text { dimensions: personal growth and } \\
\text { self-acceptance. }\end{array}$ & $\begin{array}{l}\text { The six-factor model did not show } \\
\text { good model fit indices and the } \\
\text { explanation for this is could be a } \\
\text { poor factorial validity and low } \\
\text { internal reliabilities of the scales, } \\
\text { since Ryff derived his model from } \\
\text { positive psychology and } \\
\text { psychotherapy. Findings in this } \\
\text { regard indicate an overlap in four of } \\
\text { the six dimensions (personal } \\
\text { growth, purpose in life, } \\
\text { self-acceptance and environmental } \\
\text { mastery). Finally, an items was } \\
\text { added to the } 29 \text {-item version of } \\
\text { Diaz but the model still had } \\
\text { difficulties in the model fit. }\end{array}$ \\
\hline
\end{tabular}


"a family of multivariate statistical models that allow estimating the effect and the relationships between multiple variables" (p. 34). According to these authors, these analyzes are more complex to estimate than other multivariate models such as multiple linear regression or exploratory factor analysis and can also be thought of as factor analysis models that allow the direct and indirect effects between latent factors to be evaluated. For Ruiz and colleagues (2010), one of the great strengths of this type of models, named confirmatory, is that "the fundamental interest is 'to confirm', through the analysis of the sample, the proposed relationships from the explanatory theory that has been decided to be used as a reference" (p. 34).

In order to obtain descriptive results, and to relate them to other variables or to compare their results, it is necessary to verify their psychometric properties, as well as to prove the theoretical model proposed by Ryff and taken up by different authors in different samples throughout several decades, and evaluate its adequacy. The aim of this study was to analyze the psychometric properties of the Ryff's PWBS using a structural equations model, in a sample of university students from four regions of Mexico.

\section{Method}

\subsection{Participants}

The scale was administered to 1507 university students from four cities in Mexico: Toluca, Estado de México; Ciudad Juárez, Chihuahua; Ciudad Victoria, Tamaulipas and Zacatecas, Zacatecas; with a mean age of 20.85 (S.D. = 3.41). The sample was divided into two groups; group one $(n=754)$ was used for the exploratory factor analysis and group two $(n=753)$ was used for the confirmatory factor analysis. There were no statistically significant differences between the two groups in age, gender, marital status, and city.

\subsection{Measures}

\section{Demographics}

Participants were asked about their age, gender, marital status, and city they lived in (see Table 2).

\section{Psychological Well-Being Scales (PWBS)}

The original instrument was developed by Ryff (1989b) and it consisted of six factor with 20 items per factor. van Dierendonck (2004) analyzed a shorter version of the scale with 39 items that was validated in a sample from Spain (Díaz et al., 2006). This last version of the scale was validated in this study with a structure of three factors: Self-Actualization Tendency (19 items), Interpersonal and Intrapersonal Relationships (eight items), and Autonomy (four items). The internal consistencies, measured with Cronbach's alpha, for the total of the scale and factors ranged from .63 to .92 in group one, and from .64 to .92 in group two (see Table 3). 
Table 2. Sociodemographic dates.

\begin{tabular}{|c|c|c|}
\hline & Frequency & Percentage \\
\hline \multicolumn{3}{|c|}{ City and State } \\
\hline Toluca, Estado de México & 569 & $37.7 \%$ \\
\hline Ciudad Juárez, Chihuahua & 295 & $19.6 \%$ \\
\hline Ciudad Victoria, Tamaulipas & 300 & $19.9 \%$ \\
\hline Zacatecas, Zacatecas & 343 & $22.8 \%$ \\
\hline \multicolumn{3}{|c|}{ Gender } \\
\hline Males & 512 & $34 \%$ \\
\hline Females & 995 & $66 \%$ \\
\hline \multicolumn{3}{|c|}{ Marital status } \\
\hline Single & 1369 & $90.8 \%$ \\
\hline Married & 84 & $5.6 \%$ \\
\hline Living with a romantic partner & 49 & $3.3 \%$ \\
\hline Other & 5 & $.3 \%$ \\
\hline
\end{tabular}

Table 3. Cronbach's alpha values for each factor and scale total in the two groups.

\begin{tabular}{ccc}
\hline & Group 1 & Group 2 \\
& EFA & .92 \\
\hline Factor 1 & .92 & .80 \\
Factor 2 & .79 & .64 \\
Factor 3 & .63 & .73 \\
Scale total & .75 & \\
\hline
\end{tabular}

Note: $\mathrm{EFA}=$ exploratory factor analysis; $\mathrm{CFA}=$ confirmatory factor analysis.

\subsection{Procedure}

University students were approached in four universities from different cities in Mexico. They were asked to participate, then they were given the consent form that explained the study, benefits and risks, rights and they were given the opportunity to ask questions. They were given a set of scales that took approximately 20 minutes to complete. Once they turned in the scales, they were explained the study with more details. Participants' data was captured and analyzed in SPSS 23 and AMOS 23. The sample was divided into two groups to perform an exploratory factor analysis $(\mathrm{n}=754)$ and a confirmatory factor analysis $(\mathrm{n}=753)$. The internal reliability was analyzed for the factors and the total scale in both groups.

\section{Results}

\subsection{Factor Structure of the PWBS}

The first step was to explore the factor structure of the PWBS. Exploratory factor analyses were performed with the 39 items, in a sample size of 754, using the unweighted least squares method with a direct oblimin rotation. Several factor structures with different number of factors were analyzed. For the first result, 
there were seven eigenvalues greater than one, so the first factor structure analyzed included seven factors. Even though the seven factors were analyzed, many items had shared loadings and there were factors with only two items. Other exploratory factor analyses were performed forcing the structure to six, five, four, three, two and one factors. After revising all the structures, the best fit was the analysis with three factors (see Table 4). The KMO index was .94 and the Barlett's sphericity test (Snedecor \& Cochran, 1989) indicated an adequate and normally distributed sample $(p<.01)$. For each factor, an item was retained if the highest loading had a value of 30 or greater and if the difference of the two highest loadings was at least .10;items were excluded if the highest loading of an item was less than .30 or if an item had shared factor loadings in two or more factors.

The three factor solution had 31 items with unique factor loadings from .42 to .75 (see Table 5), six items were excluded because of shared factor loadings

Table 4. Factor Loadings and Communalities for Exploratory Factor Analysis of PWBS.

\begin{tabular}{|c|c|c|c|c|}
\hline \multirow[b]{2}{*}{ Item } & \multicolumn{3}{|c|}{ Factor loadings } & \multirow{2}{*}{$\mathrm{h}^{2}$} \\
\hline & $\mathrm{F} 1$ & $\mathrm{~F} 2$ & F3 & \\
\hline 1. When I look at the story of my life, I am pleased with how things have turned out & .57 & -.28 & .29 & .36 \\
\hline 2. I often feel lonely because I have few close friends with whom to share my concerns & -.22 & .50 & -.30 & .28 \\
\hline $\begin{array}{l}\text { 3. I am not afraid to voice my opinions, even when they are in opposition to the opinions of } \\
\text { most people }\end{array}$ & .41 & -.11 & .37 & .24 \\
\hline 4. I am concerned about how other people evaluate the choices I have made in my life & -.23 & .25 & -.55 & .31 \\
\hline 5. I have difficulty arranging my life in a way that is satisfying to me & -.35 & .45 & -.41 & .32 \\
\hline 6. I enjoy making plans for the future and working to make them a reality & .65 & -.20 & .19 & .43 \\
\hline 7. In general, I feel confident and positive about myself & .71 & -.24 & .44 & .56 \\
\hline 8. I don't have many people who want to listen when I need to talk & -.22 & .56 & -.24 & .33 \\
\hline 9. I tend to worry about what other people think of me & -.27 & .26 & -.67 & .45 \\
\hline $\begin{array}{l}\text { 10. I judge myself by what I think is important, not by the values of what others think is } \\
\text { important }\end{array}$ & .27 & .17 & .09 & .13 \\
\hline 11. I have been able to build a home and a lifestyle for myself that is much to my liking & .47 & -.17 & .24 & .23 \\
\hline 12. I am an active person in carrying out the plans I set for myself & .68 & -.18 & .28 & .46 \\
\hline 13. Given the opportunity, there are many things about myself that I would change & -.10 & .41 & -.40 & .25 \\
\hline 14. I feel like I get a lot out of my friendships & .45 & -.12 & -.03 & .24 \\
\hline 15. I tend to be influenced by people with strong opinions & -.03 & .23 & -.43 & .21 \\
\hline 16. In general, I feel I am in charge of the situation in which I live & .53 & .01 & .16 & .29 \\
\hline 17. I feel good when I think of what I've done in the past and what I hope to do in the future & .68 & -.19 & .27 & .46 \\
\hline 18. My aims in life have been more a source of satisfaction than frustration to me & .66 & -.21 & .26 & .44 \\
\hline 19. I like most aspects of my personality & .69 & -.17 & .40 & .51 \\
\hline 20. It seems to me that most other people have more friends than I do & -.17 & .58 & -.26 & .34 \\
\hline 21. I have confidence in my opinions, even if they are contrary to the general consensus & .56 & -.04 & .47 & .44 \\
\hline
\end{tabular}




\section{Continued}

22. The demands of everyday life often get me down

\begin{tabular}{|c|c|c|c|}
\hline-.24 & .53 & -.34 & .31 \\
\hline .68 & -.22 & .26 & .47 \\
\hline .68 & -.13 & .22 & .47 \\
\hline-.36 & .53 & -.34 & .36 \\
\hline-.21 & .57 & -.23 & .33 \\
\hline-.17 & .35 & -.40 & .21 \\
\hline .57 & -.15 & .20 & .33 \\
\hline-.37 & .49 & -.32 & .33 \\
\hline-.38 & .49 & -.33 & .34 \\
\hline .72 & -.27 & .27 & .54 \\
\hline .57 & -.24 & .08 & .37 \\
\hline-.19 & .31 & -.42 & .21 \\
\hline .05 & .10 & -.01 & .01 \\
\hline .55 & -.02 & .10 & .31 \\
\hline-.22 & .31 & -.26 & .14 \\
\hline .75 & -.19 & .28 & .56 \\
\hline .75 & -.14 & .22 & .57 \\
\hline .50 & -.04 & .11 & .25 \\
\hline
\end{tabular}

23. I have a sense of direction and purpose in life

24. In general, I feel that I continue to learn more about myself as time goes by

25. In many ways, I feel disappointed about my achievements in my life

26. I have not experienced many warm and trusting relationships with others

27. It's difficult for me to voice my own opinions on controversial matters

28. I am quite good at managing the many responsibilities of my daily life

29. I don't have a good sense of what it is I'm trying to accomplish in my life

30. I gave up trying to make big improvements or change in my life a long time ago

31. For the most part, I am proud of who I am and the life I lead

32. I know that I can trust my friends, and they know they can trust me

33. I often change my mind about decisions if my friends or family disagree

34. I don't want to try new ways of doing things-my life is fine the way it is

35. I think it is important to have new experiences that challenge how you think about yourself and the world

36. When I think about it, I haven't really improved much as a person over the years

37. I have a sense that I have developed a lot as a person over time

38. For me, life has been a continuous process of learning, changing, and growth

39. If I were unhappy with my living situation, I would take effective steps to change it.

Note: Items with bolded loadings are items retained in that factor; F1 = Personal Orientation; F2 = Positive Relationships; F3 = Autonomy.

Table 5. Completely Standardized Factor Loadings of the Confirmatory Factor Analysis.

\begin{tabular}{ll}
\hline Item & Factor loadings \\
\hline Factor 1 & .59 \\
Item 1 & .65 \\
Item 6 & .70 \\
Item 7 & .45 \\
Item 11 & .66 \\
Item 12 & .43 \\
Item 14 & .44 \\
Item 16 & .72 \\
Item 17 & .72 \\
Item 18 & .69 \\
Item 19 & .66 \\
Item 23 & .66 \\
Item 24 & .60 \\
Item 28 & .81 \\
Item 31 &
\end{tabular}




\begin{tabular}{ll}
\hline Item 32 & .55 \\
Item 35 & .46 \\
Item 37 & .69 \\
Item 38 & .73 \\
Item 39 & .47 \\
Factor 2 & \\
Item 2 & .57 \\
Item 8 & .58 \\
Item 20 & .53 \\
Item 22 & .59 \\
Item 25 & .70 \\
Item 26 & .52 \\
Item 29 & .64 \\
Item 30 & .51 \\
Factor 3 & .46 \\
Item 4 & .74 \\
Item 9 & .71 \\
Item 15 & .35 \\
Item 33 & \\
\hline
\end{tabular}

(items 3, 5, 13, 21, 27, and 36) and two items were excluded because of low factor loading values (items 10 and 34 ). The first factor explained $26.96 \%$ of the total variance, and it was composed of 19 items with factor loadings ranging from .45 to .75. According to the theme of these items, this factor was named "Self-Actualization Tendency". An item for this factor is "In general, I feel confident and positive about myself". The second factor explained $8.31 \%$ of the total variance and it consisted of eight items with a range of factor loadings from .49 to .58. The theme for these items was "Interpersonal and Intrapersonal Relationships" and an item from this factor was "I often feel lonely because I have few close friends with whom to share my concerns". The third factor explained $4.05 \%$ of the total variance and it included four items with factor loading values between .42 to .67; the theme for these items was "Autonomy" and an item from this factor was "I tend to worry about what other people think of me".

The Cronbach's alpha was used to evaluate the internal reliability of the sum of all of the items of the scale and for each factor (see Table 3). The internal reliability for all of the items was $\alpha=.77$, for the first factor was $\alpha=.92$, for the second factor was $\alpha=.79$ and for the third factor was $\alpha=.63$.

\subsection{Confirmation of Factor Structure of the PWBS}

A confirmatory factor analysis, with a sample of 753 participants, was used to 
cross validate the factor structure of the PWBS. The model for this analysis included the three factors from the previous analysis and with a total of 31 items. To calculate the model, the variance of an item per factor had to be constrained to one. According to Hu and Bentler (1999), to evaluate the model fit, the following cut-off points per index describe a good model fit: RMSEA $\leq .06$, CFI $\geq .90$, NFI $\geq .90$, and GFI $\geq .90$ (Hu \& Bentler, 1999). The model fit for the scale with a structure of three factors was evaluated, and it had the following fit indices: $\mathrm{RMSEA}=.05, \mathrm{CFI}=.90, \mathrm{NFI}=.86, \mathrm{GFI}=.89, \chi^{2}(427)=1356.15(p<.01)$, and $\chi^{2} / \mathrm{df}=3.18$. A good model fit should not have a significant $\chi^{2}$ value, but it is important to note that the $\chi^{2}$ index is sensitive to large sample sizes (Cheung \& Rensvold, 2002).

Factor loadings for all of the items are reported in Table 4. The range of the factor loadings for the first factor was from .43 to .81 , for the second factor was from .51 to .70 , and for the third factor was from .35 to .74 . The internal reliability of all of the items was $\alpha=.73$, for the first factor was $\alpha=.92$, for the second factor was $\alpha=.80$, and for the third factor was $\alpha=.64$.

\subsection{Correlations among Factors}

Finally, we correlated the factors of the adapted version in this study, finding values ranging between $r=-.67$ and $r=.68$, both positive or negative according to the content of each factor (see Table 6).

\section{Discussion}

\subsection{Factor Structure of the PWBS}

The different versions (of 29, 39, 54 and 84 items) of the Ryff s PWBS in Spanish (Table 1), have been tested in studies with Spanish and Latin American samples (including Dominican Republic, Mexico, Colombia and Puerto Rico) with samples of adolescents, adults, elderly, or general samples. The results of these studies indicate dimensions of two, four, five and six factors without second order factors, as well as six factors with one or two second order factors. As discussed in the introduction of this work and as observed in the studies in Table 1, while some studies obtain a structure similar to that of Ryff's original proposal (Gallardo \& Moyano-Díaz, 2012; Ryff \& Singer, 2006; Rosa-Rodríguez et al., 2015), others have obtained somewhat different results different from the factorial structure of origin (Abbot et al., 2006; Springer, Hauser, \& Freese, 2006; Valenzuela, 2015).

Table 6. Correlations among the factors of the Ryff's PWBS.

\begin{tabular}{cccc}
\hline & TA & RIeI & AU \\
\hline Tendency to self-actualization (TA) & - & & \\
Interpersonal and intrapersonal relations (RIeI) & $-.67^{\star *}$ & - & \\
Autonomy (AU) & $-.41^{* *}$ & $.68^{\star *}$ & - \\
\hline
\end{tabular}

${ }^{* *} p<.01$. 
Based on these inconsistencies and in accordance with the literature reviewed, there was a need to evaluate the factorial structure of the test in its version with 39 items, which was the purpose of this research. Since the estimation of a model begins with the formulation of a theory that can be tested with real data (Ruiz et al., 2010), the exploratory and confirmatory analyses, revealed that the factor structure with the best model fit (Hu \& Bentler, 1999; Ruiz et al., 2010) was the one that grouped the items into three factors: Tendency to Self-actualization, Interpersonal and Intrapersonal Relations, and Autonomy.

Regarding the first factor, Tendency to Self-actualization, items were grouped together to conform a new dimension that included items that in the original version of the scales belonged to the factors of Purpose in Life, Self-Acceptance, Environmental Mastery and Personal Growth.

One of the basic theories of psychological well-being is positive psychology and further backward are the humanist theories commanded by authors such as Abraham Maslow (as cited in Lafarga Corona \& Gómez del Campo, 1989), whose contribution was the hierarchy of human needs. At its highest level, Maslow presents self-actualization, also called personal guidance. In his studies, he indicated that these needs for self-actualization are needs of growth or being, which are not born of the lack of something, but of the desire for personal growth and that individuals who have good psychological functioning are characterized by a tendency to self-actualize (competence, strength, and awareness of weaknesses).

It was later when Everett Shostrom (1964) operationalized the construct of self-actualization by indicating that self-actualizing people experience themselves as being capable of becoming angry (acceptance of aggression); experience and accept their weaknesses (self-acceptance); they are able to be loving with others (ability to intimate contact) and with themselves (self-esteem); they accept the values of others and are flexible in applying their own values; they attend to their own needs and feelings and are sensitive to the needs of others; they manage to find meaning in their experiences (purpose of life); are interested in reaching their maximum potential, are concerned about their growth (personal) and can see the difficulties of life as challenges (environmental mastery).

The 14 items of the tendency to self-actualization refer to positive aspects related to self-learning, to finding direction and goals in life, to the ability to handle responsibilities in life and to make changes if necessary, to feel safe and positive with oneself, and these items represent the most powerful domain of the scales. Findings that are not similar, but consistent with the way these factors were configured in this new dimension are those of Chitgian-Urzúa et al. (2013) who found that the dimensions of environmental mastery and self-acceptance have high correlations with each other, as well as purpose inlife and self-acceptance, so they indicate that they seem to be measuring the same construct, and in this study, these four dimensions merge in a new factor, revisiting the postulates of humanistic psychology as a background that supports psychological well-being. 
The second factor, called interpersonal and intrapersonal relations, groups eight items that in the original version of Diaz et al. (2006) belong to the factors positive relations with others (four reactants), environmental mastery, purpose in life, personal growth and autonomy (with an item from each factor, respectively) and that in this study evaluate the difficulty of maintaining close relationships and of trust with others, of being disappointed by one's own achievements, of difficulties in accepting oneself, or of feeling that the demands of daily life depress and overwhelm the person.

As Ryff points out, one of the components of psychological well-being is the ability to engage and maintain close and warm relationships with other people, to care about the well-being of others, and strong empathy. This component in the Ryff model, called positive relations with others, would also have its negatively written items, deficits that the person experiences in affection, intimacy and empathy towards the others, since the loadings of the four items have a negative sign, and for this reason it was decided to call it interpersonal relations.

In the same way, this second factor integrates four other items whose content refers to negative attitudes towards oneself, not accepting positive aspects of oneself, not knowing clearly what one wants in life and a negative assessment of the person's past, which when integrated would reveal a deficit in the acceptance and view of oneself and it corresponds to that relationship with oneself (intrapersonal from the humanistic psychology view).

The third factor, autonomy, includes four items that in the version of Diaz et al. (2006) belonged to the dimension denominated autonomy, although it retains less items than the version translated into Spanish and contains those of negative type. The items for this factor reflect the concern for the evaluation that others make of the person, of his vital choices, of the possible influence that others exert on the person and of changing the own decisions if others do not agree with them. Unlike the other two factors, which group items of different dimensions, the autonomy factor groups only four items that in the original scale were included in the dimension of the same name.

The analysis of the different Spanish versions of the Ryff s PWBS presented in Table 1 indicates that in two studies the factor structure was not analyzed and in five of them the factor analyses carried out was of confirmatory type, forcing the structure to six dimensions. The rest of the studies presented in Table 1, performed an exploratory or exploratory and confirmatory analyzes in the same study. In our study, we performed an exploratory and confirmatory factor analyses in order to ensure that the scale's dimensionality was the most adequate.

In this sense, the contribution of this study is that according to the contradictory findings of previous studies, several models were tried in our analyses, in the understanding that the structural equation models "facilitate the adequate statistical framework to evaluate the validity and reliability of each item rather than a global analysis, helping the researcher to optimize both the construction of a measurement instrument and the analysis of results" (Escobedo Portillo, 
Hernández Gómez, Estebané Ortega, \& Martínez Moreno, 2016: p. 19), which guarantees a greater precision of the findings regarding the dimensional structure of the PWBS.

After explaining each of the factors from this study, our findings support a three-dimensional structure as the one obtained by Kafka and Kozma (2002) who found a three-factorstructure because the one proposed by Ryff was not replicated in their study even though they found the same face validity as Ryff. Springer and Hauser (2006) found a similar overlap between the factors of personal growth, purpose in life, self-acceptance and environmental mastery, which in this research were grouped in the first factor we named tendency to self-actualization. These authors do not criticize the theoretical model generated by Ryff, but criticize the way psychological well-being is operationalized, since there is an interdependence of the dimensions, revealed by the high correlations among the factors, so it could be presumed that the items of these dimensions are actually measuring the same construct. Later, Springer, Hauser and Freese (2006) reveal in a new study that there are high correlations among four of the six dimensions of the Ryff's model, which means that the items do not discriminate sufficiently the construct. Findings similar to those of Springer and Hauser are reported later by Valenzuela (2015), who with a sample of university students reported that the six-factor structure has inappropriate model fit indices and a low internal consistency; this author found that a two-factor model (personal growth and self-acceptance) has a better model fit and he also concludes that there is a one-dimensional overlap of the factors of personal growth, purpose in life, self-acceptance and environmental mastery.

As Gallardo and Moyano-Díaz (2012) argued in an analysis of the PWBS, that the model proposed by Ryff has had an important weight in the literature on psychological well-being; however, it would be necessary to review in detail the dimensions originally proposed, in order to inquire whether a new version or a reconfiguration of the dimensions is needed, because in some cases the results of the replications are different from the original model. So far, a first finding in our study on the Ryff's PWBS is that the factor analysis does not indicate a good theoretical fit of the six-factor structure initially proposed by Ryff (1989a) and subsequently translated, reformulated, and adapted by Díaz et al. (2006), but in our study the model with the best model fit is that of three factors.

\subsection{Reliability of the PWBS}

With regard to the reliability, the internal reliability of the total scale $(\alpha=.73)$ as well as the second factor $(\alpha=.80)$, are acceptable; in the case of the alpha value of the first factor is high (.92) and that of the third factor has a low value ( $a$ $=.64)$. The low value of the third factor and the acceptable value of the total scale are considered adequate in exploratory studies (Nunnally, 1980) but not desirable in confirmatory studies since the Ryff measure, has shown higher alpha values several other studies. 
The internal reliabilities obtained in this research share similarities with the findings of Gallardo and Moyano-Díaz (2012), who found between acceptable and bad consistencies in three scales and good consistencies in the other three; Medina-Calvillo et al. (2003) found an acceptable total consistency in the subscales; Rosa Rodríguez et al. (2015) obtained low internal consistencies in the environmental mastery and in personal growth factors; Valenzuela (2015) indicated that internal consistencies are far from the recommended standards; Véliz (2012) found lower consistencies in comparison to the results of previous studies; Vera-Villarroel et al. (2013) reveal that four of the six scales do not have good internal consistencies, and Vivaldi and Barra (2012) concluded that two of the six factors have reliability problems. These findings, on internal consistencies, are different from those reported by Díaz et al. (2006), Díaz, Stavraki, Blanco and Gandarillas (2015), Chitgián-Urzúa et al. (2013), Loera Malvaez et al. (2008), Molina Sena and Meléndez Moral (2006) and van Dierendonck et al. (2008), who report good or high consistency values with different samples.

Although the reliability is a necessary, but not sufficient, condition to guarantee the validity of an instrument (Campo-Arias \& Oviedo, 2008), it is desirable that this property, that reveals the magnitude in which the items measure the same construct, has values in a certain range to demonstrate the degree of homogeneity of the measure.

In addition to the findings that support the difficulties of the internal consistencies of the Ryffs PWBS, there is another explanation supported by Campos-Arias and Oviedo (2008) who state that better reliability indices "are achieved when the instrument is applied in a sufficiently heterogeneous population in relation to the attribute or characteristic that is intended to be measured" (p.837), so as a suggestion, it would be interesting to see how the internal consistencies behave when performed with different age groups in the same study, since in this research, we worked with samples of young people.

Based on the reliability data of the scales and the total test in this study, a second important point is that the internal consistencies observe some difficulties and would support the findings of authors who have found similar results, and that these values are far from the high values reported in other studies.

The confirmatory analysis of the Ryff's PWBS included the use of fit indices that allowed verifying the suitability of the model. If we compare the model fit indices proposed by Hu and Bentler (1999) and by Ruiz et al. (2010), with those obtained in the confirmatory factor analysis of this study, it is clear that in this sample of university students, from four Mexican states, the model that showed the best fit was the one that allowed to keep all the original items of the scale and that simplified the factorial structure in three factors.

\subsection{Correlation between Factors of the PWBS}

The discriminant validity of the scale was contrasted by the traditional way of calculating the correlation matrix among the factors of the scales. The correla- 
tion between the factors of tendency to self-actualization (whose items are written in a positive sense) and interpersonal and intrapersonal relations (with negatively worded items) reveal a moderate and negative correlation; between the factor of tendency to self-actualization and the factor of autonomy (the latter, with negatively worded items) the correlation is negative and low; The correlation between the factor of interpersonal and intrapersonal relations and the factor of Autonomy (both, with negatively worded items) was moderate and positive. The results of these correlations in the validated version of the scale in this study indicate that the regrouping of the factors of the original scale in a three-dimensional version reveals better values than those obtained in other studies, which are detailed below.

In some studies, (Chitgian-Urzúa et al., 2013; Gallardo \& Moyano-Díaz, 2012; Springer, Hauser, \& Freese, 2006; Véliz, 2012) inter-item correlations or between scales reveal high values, which are indicative that there are items or scales that are assumed to be independent but they might actually be evaluating similar aspects. In some cases, there is a model with six dimensions but with a high intercorrelations among factors, which undermines the discriminant validity of the scales, and perhaps this overlap also undermines the construct validity of the test.

For Gallardo and Moyano-Díaz (2012), the proposed model by Ryff has had a very important weight in the literature of positive psychology, nevertheless, based on these findings, it is convenient to think that the raised dimensions are subject to revision to see if a new version arises, since the results of the high correlations among factors would presume an overlap among them, this would also explain that some of the dimensions coalesce with each other.

Véliz (2012) indicates that one of the problems of the Ryffs PWBS in its Spanish version is that a six-factor model is difficult to replicate because there are high intercorrelations among the factors, which does not contribute to the discriminant validity that the authors of the scale defend. Véliz defends the idea that in order to improve the results of the scales, studies with larger samples should be carried out, an action that is presented in this study; although we have a large sample, the scales still present difficulties to fit a model of six factors, but problems with the internal consistencies in this modified version are no longer present.

As an important information on Ryff's PWBS, the analyzes of the correlations among factors are indicative of a greater interdependence, which allows to appreciate that these are factors or dimensions more or less independent although part of a common construct, and that in this study there is no overlap between scales as it is reflected in other reviewed studies.

\section{Conclusion}

Ryff's PWBS had a great success after the emergence of the term at the time they were developed and for the novelty of being able to evaluate the construct under 
different conditions. Different versions were made, some shorter, others with a greater number of items and in different languages, when they were analyzed with confirmatory or exploratory factor analyzes, they did not always replicated the original model. So far, it seems that there are conditions associated with age, gender, social context and sample size that are affecting the replicability of the model, which would affect the internal consistency of the test and its discriminant validity. Nevertheless, this study had a sufficiently large sample size and diverse contexts, which would guarantee the criteria indicated by Ruiz et al. (2010) regarding the fact that sample sizes greater than 200 participants guarantee better results. Thus, the general conclusion is that our data, regarding the Ryff's PWBS, are contradictory to the original model and that the hexadimensional model is not confirmed, so the model does not replicate the same in all contexts and samples.

\section{Suggestions}

Based on the findings, the suggestions on the Ryff's PWBS are that studies focusing on the adaptation of the construct be made from emerging theories in positive psychology, as the term theorized by Ryff emerged in the 1960s (Oramas Viera et al., 2006) in which the central topic was happiness, while nowadays the topic of positive psychology is more focused on well-being, which is the gold standard for this perspective (Dodge, Daly, Huyton, \& Sander, 2012). On the other hand, a careful analysis of the PWBS items is also suggested, since probably in practice these items do not operationalize the proposed constructs from the theory. It is also suggested to carry out studies with varied age samples and to analyze the association of the PWBS with other variables to see how the psychological well-being construct behaves in relation to sociodemographic aspects, and finally, it is suggested a deep study of the PWBS from the hedonic and eudemonic perspectives, since there are findings (Barrantes-Brais \& Ureña-Bonilla, 2015, Triadó et al., 2007; Valenzuela, 2015) regarding the fact that the test captures these two aspects of well-being.

\section{Conflicts of Interest}

The authors declare no conflicts of interest regarding the publication of this paper.

\section{References}

Abbot, R. A., Ploubidis, G. B., Huppert, F. A., Kuh, D., Wadsworth, M. E., \& Croudace, T. J. (2006). Psychometric Evaluation and Predictive Validity of Ryff's Psychological Well-Being Items in a UK Birth Cohort Simple of Women. Health and Quality of Life Outcomes, 4, 1-16. https://doi.org/10.1186/1477-7525-4-76

Ballesteros, B. P., Medina, A., \& Caycedo, C. (2006). El bienestar psicológico definido por asistentes a un servicio de consulta psicológica en Bogotá, Colombia. Universitas Psychologica, 5, 239-258.

Barrantes-Brais, K., \& Ureña-Bonilla, P. (2015). Bienestar psicológico y bienestar subjetivo en estudiantes universitarios costarricenses. Revista Intercontinental de Psicología y 
Educación, Enero-junio, 101-123.

Campo-Arias, A., \& Oviedo, H. C. (2008). Propiedades psicométricas de una escala: La consistencia interna. Revista de Salud Pública, 10, 831-839. https://doi.org/10.1590/S0124-00642008000500015

Casas, F., Rosich, M., \& Alsinet, C. (2000). El bienestar psicológico de los preadolescentes. Anuario de Psicología, 31, 73-86.

Castro-Solano, A. (2009). El bienestar psicológico: Cuatro décadas de progreso. Revista Interuniversitaria de Formación del Profesorado, 23, 43-72.

Casullo, M. M., \& Castro-Solano, A. (2002). Patrones de personalidad, síndromes clínicos y bienestar psicológico en adolescentes. Revista de Psicopatología y Psicología Clínica, 7, 129-140. https://doi.org/10.5944/rppc.vol.7.num.2.2002.3927

Cheung, G. W., \& Rensvold, R. B. (2002). Evaluating Goodness-of-Fit Indexes for Testing Measurement Invariance. Structural Equation Modeling, 9, 233-255. https://doi.org/10.1207/S15328007SEM0902_5

Chitgian-Urzúa, V., Urzúa, M. A., \& Vera-Villarroel, P. (2013). Análisis preliminar de las Escalas de Bienestar Psicológico en población chilena. Revista Argentina de Clínica Psicológica, XXII, 5-14.

Cornejo, M., \& Lucero, M. C. (2005). Preocupaciones vitales en estudiantes universitarios relacionado con bienestar psicológico y modalidades de afrontamiento. Fundamentosen Humanidades, VI, 143-155.

Costa, P., \& McCrae, R. (1980). Influence of Extraversion and Neuroticism on Subjetive Well-Being: Happy and Unhappy People. Journal of Personality and Social Psychology, 38, 668-678. https://doi.org/10.1037/0022-3514.38.4.668

Díaz, D., Rodríguez-Carvajal, R., Blanco, A., Moreno-Jiménez, B., Gallardo, I., Valle, C., \& van Dierendonck, D. (2006). Adaptación española de las escalas de bienestar psicológico de Ryff [Spanish Adaptation of the Psychological Well-Being Scales of Ryff]. Psicothema, 18, 572-577.

Díaz, D., Stavraki, M., Blanco, A., \& Gandarillas, B. (2015). The Eudaimonic Component of Satisfaction with Life and Psychological Well-Being in Spanish Cultures. Psicothema, 27, 247-253. https://doi.org/10.7334/psicothema2015.5

Dodge, R., Daly, A. P., Huyton, J., \& Sander, L. D. (2012). The Challenge of Defining Well-Being. International Journal of Wellbeing, 2, 222-235. https://doi.org/10.5502/ijw.v2i3.4

Domínguez Lara, S. E. (2014). Análisis psicométrico de la Escala de Bienestar Psicológico para adultos en estudiantes universitarios de Lima: Un enfoque de ecuaciones estructurales. Psychologia: Avances de la Disciplina, 8, 23-31.

https://doi.org/10.21500/19002386.1211

Escobedo Portillo, M. T., Hernández Gómez, J. A., Estebané Ortega, V., \& Martínez Moreno, G. (2016). Structural Equation Modeling: Features, Phases, Construction, Implementation and Results. Ciencia \& Trabajo, 18, 16-22. https://doi.org/10.4067/S0718-24492016000100004

Gallardo, I., \& Moyano-Díaz, E. (2012). Análisis psicométrico de las escalas Ryff (versión española) en una muestra de adolescentes chilenos. Universitas Psychologica, 11, 931-939.

García-Alandete, J. (2013). Bienestar psicológico, edad y género en universitarios españoles. Salud \& Sociedad, 4, 48-58.

https://doi.org/10.22199/S07187475.2013.0001.00004

García-Viniegras, C. R. V. (2005). El bienestar psicológico: Dimensión subjetiva de la 
calidad de vida. Revista Electrónica de Psicología Iztacala, 8, 1-20.

García-Viniegras, C. R. V., \& González-Benítez, C. (2000). La categoría bienestar psicológico: Su relación con otras categorías sociales. Revista Cubana de Medicina General Integral, 16, 586-592.

Hu, L., \& Bentler, P. (1999). Cutoff Criteria for Fit Indices in Covariance Structure Analysis: Conventional Criteria versus New Alternatives. Structural Equation Modeling, 6, 1-55. https://doi.org/10.1080/10705519909540118

Kafka, G. J., \& Kozma, A. (2002). The Construct Validity of Ryff's Scales of Psychological Well-Being (PWBS) and Their Relationships to Measures of Subjective Well-Being. Social Indicators Research, 57, 171-190. https://doi.org/10.1023/A:1014451725204

Lafarga Corona, J., \& Gómez del Campo, J. (1989). Desarrollo de potencial humano. Aportaciones de una psicología humanista (Volume 3). México: Trillas.

Loera-Malvaez, N., Balcázar-Nava, P., Trejo-González, L., Gurrola-Peña, G. M., \& Bonilla-Muñoz, M. P. (2008). Adaptación de la Escala de Bienestar Psicológico de Ryff en adolescentes preuniversitarios. Neurología, Neurocirugía y Psiquiatría, 41, 90-97.

Marías, J. (1987). La felicidad humana. Madrid: Alianza Editorial.

Medina-Calvillo, M. A., Gutiérrez-Hernández, C. Y., \& Padrós-Blázquez, F. (2013). Propiedades psicométricas de la Escala de Bienestar Psicológico de Ryff en población mexicana. Revista de Educación y Desarrollo, 27, 25-30.

Molina Sena, C. J., \& Meléndez Moral, J. C. (2006). Bienestar psicológico en envejecientes de la República Dominicana. Geriátrika, 22, 97-105.

Nunnally, J. C. (1980). Teoría Psicométrica. México: Trillas.

Oramas Viera, A., Santana López, S., \& Vergara Barrenechea, A. (2006). El bienestar psicológico, un indicador positivo de la salud mental. Revista Cubana de Salud y Trabajo, 7, 34-39.

Rosa-Rodríguez, Y., \& Quiñones Berrios, A. (2012). El bienestar psicológico en el proceso de ayuda con estudiantes universitarios. Revista Griot, 5, 7-17.

Rosa-Rodríguez, Y., Negrón Cartagena, N., Maldonado Peña, Y., Quiñones Berrios, A., \& Toledo Osorio, N. (2015). Dimensiones del bienestar psicológico y apoyo social percibido con relación al sexo y nivel de estudio en universitarios. Avances en Psicología Latinoamericana, 33, 31-43. https://doi.org/10.12804/apl33.01.2015.03

Ruiz, M. A., Pardo, A., \& San Martín, R. (2010). Modelos de ecuaciones estructurales. Papeles del Psicólogo, 31, 34-45.

Ryff, C. D. (1989a). Happiness Is Everything, or Is It? Explorations on the Meaning of Psychological Well-Being. Journal of Personality and Social Psychology, 57, 1069-1081. https://doi.org/10.1037/0022-3514.57.6.1069

Ryff, C. D. (1989b). Beyond Ponce de Leon and Life Satisfaction: New Directions in Quest of Successful Aging. International Journal of Behavioral Development, 12, 35-55. https://doi.org/10.1177/016502548901200102

Ryff, C. D., \& Singer, B. H. (2006). Best News Yet on the Six-Factor Model of Well-Being. Science Direct, 33, 1106-1119. https://doi.org/10.1016/j.ssresearch.2006.01.002

Shostrom, E. L. (1964). An Inventory for the Measurement of Self-Actualization. Educational and Psychological Measurement, 24, 207-218. https://doi.org/10.1177/001316446402400203

Snedecor, G. W., \& Cochran, W. G. (1989). Statistical Methods (8th ed.). Ames, IA: Iowa State University Press.

Springer, K. W., \& Hauser, R. M. (2006). An Assessment of the Construct Validity of 
Ryff's Scales of Psychological Well-Being: Method, Mode, and Measurements Effects. Social Science Research, 35, 1080-1102. https://doi.org/10.1016/j.ssresearch.2005.07.004

Springer, K. W., Hauser, R. M., \& Freese, J. (2006). Bad News Indeed for Ryff s Six-Factor Model of Well-Being. Social Science Research, 35, 1120-1131.

https://doi.org/10.1016/j.ssresearch.2006.01.003

Tomás Miguel, J. M., Meléndez Moral, J. C., \& Navarro Pardo, E. (2008). Modelos factoriales confirmatorios de las escalas de Ryff en una muestra de personas mayores. Psicothema, 29, 304-310.

Triadó, C., Villar, F., Solé, C., \& Cedrán, M. (2007). Construct Validity of Ryff's Scale of Psychological Well-Being in Spanish Older Adults. Psychological Reports, 100, 1151-1164. https://doi.org/10.2466/pr0.100.4.1151-1164

Valenzuela, J. E. (2015). Bienestar psicológico en una muestra de estudiantes universitarios mexicanos. Psicumex, 5, 4-19.

van Dierendonck, D. (2004). The Construct Validity of Ryff's Scales of Psychological Well-Being and Its Extension with Spiritual Well-Being. Personality and Individual Differences, 36, 629-643. https://doi.org/10.1016/S0191-8869(03)00122-3

van Dierendonck, D., Díaz, D., Rodríguez-Carvajal, R., Blanco, A., \& Moreno-Jiménez, B. (2008). Ryff's Six-Factor Model of Psychological Well-Being, a Spanish Exploration. Social Indicators Research, 87, 473-479. https://doi.org/10.1007/s11205-007-9174-7

Véliz, A. (2012). Propiedades psicométricas de la Escala de Bienestar Psicológico y su estructura factorial en universitarios chilenos. Psicoperspectivas, Individuo y Sociedad, 11, 143-163.

Vera-Villarroel, P., Urzúa, M. A., Silva, J. R., Pavés, P., \& Celis-Atenas, K. (2013). Escala de Bienestar de Ryff: Análisis comparativo de los modelos teóricos en distintos grupos de edad. Psicología: Reflexao e Crítica, 26, 106-112. https://doi.org/10.1590/S0102-79722013000100012

Villar, F., Triadó, C., Resano, C. S., \& Osuna, M. J. (2003). Bienestar, adaptación y envejecimiento: Cuando la estabilidad significa cambio. Revista Multidisciplinaria de Gerontología, 13, 152-162.

Vivaldi, F., \& Barra, E. (2012). Bienestar psicológico, apoyo social percibido y percepción de salud en adultos mayores. Terapia Psicológica, 30, 23-29.

https://doi.org/10.4067/S0718-48082012000200002 